\title{
PENERAPAN ALGORITMA K-MEANS DAN METODE MARKETING MIX DALAM SEGMENTASI MAHASISWA DAN STRATEGI PEMASARAN
}

\author{
Siti Monalisa*1, Tengku Nurainun ${ }^{2}$, Misra Hartati ${ }^{3}$ \\ ${ }^{1}$ Jurusan Sistem Informasi Universitas Islam Negeri Sulthan Syarif Kasim \\ 2,3 Jurusan Teknik Industri Universitas Islam Negeri Sulthan Syarif Kasim \\ Email: ${ }^{1}$ siti.monalisa@uin-suska.ac.id, ${ }^{2}$ t.nurainun@uin-suska.ac.id, ${ }^{3}$ misra.hartati@uin-suska.ac.id \\ *Penulis Korespondensi
}

(Naskah masuk: 15 April 2019, diterima untuk diterbitkan: 01 Februari 2021)

\begin{abstract}
Abstrak
Idealnya, semakin tinggi jumlah pendaftar di suatu institusi pendidikan, semakin tinggi kualitas dari mahasiswa yang diterima. Akan tetapi, kondisi ideal ini tidak dicapai oleh Fakultas Sains dan Teknologi (FST) UIN Suska Riau disebabkan karena sedikitnya jumlah mahasiswa yang berasal dari sekolah menengah unggul yang mendaftar sebagai mahasiswa di FST UIN Suska Riau. Berdasarkan survey terhadap dosen di FST UIN Suska, masih terdapat kendala yang cukup besar dalam proses transfer ilmu kepada mahasiswa terutama dalam hal daya tangkap dan pemahaman mahasiswa terhadap materi ajar. Oleh karena itu, analisis lebih lanjut mengenai mahasiswa saat ini diperlukan untuk merancang sebuah strategi bagaimana menarik minat siswa yang berasal dari sekolah menengah unggul untuk mendaftar sebagai mahasiswa di FST UIN Suska Riau. Metodologi yang digunakan dalam penelitian ini adalah segmentasi mahasiswa menggunakan algoritma K-Means dan teknik kluster menggunakan algoritma Dunn Index. Pengumpulan data dilakukan sebanyak 614 mahasiswa FST tahun ajaran 2015 sampai 2017. Output dari segmentasi mahasiswa digunakan untuk menentukan target dari Marketing Mix 7P. Penelitian ini menghasilkan 2 kluster mahasiswa dengan nilai Dunn Index 1,99. Kuesioner disebarkan kepada mahasiswa dari dua kluster yang berbeda tersebut dan hasilnya menunjukkan bahwa terdapat tiga variabel Marketing Mix yang berpotensi untuk meningkatkan target pasar yaitu people, product, dan place.
\end{abstract}

Kata kunci: dunn index, FST UIN Suska, k-means, marketing mix, strategi

\section{IMPEMENTATION OF K-MEANS ALGORTHM DAN MARKETING MIX ON STUDENTS SEGMENTATION DAN MARKETING STRATEGY}

\begin{abstract}
Ideally, the higher number of registrant in an educational institution, the higher quality of the accepted students. But, this ideal condition was not achieved by Faculty of Science dan Technology UIN Suska Riau due to the minimum number of students from top ranking senior high school who registered as student in FST UIN Suska Riau. Based on a survey of lecturers at FST UIN Suska, there are still significant limitations in the process of transferring knowledge to students, especially in terms of catching dan understdaning students towards teaching materials. Therefore, further analysis of current input of students is needed to design a strategy how to attract the high quality of high school students to register as student in FST UIN Suska Riau. The methodology in this research are student segmentations using K-Means Algorithm dan Clustering with Dunn Index Algorithm. The data collection derived from 614 students of FST in academic year 2015 until 2017. The output of student segmentations were used to determine the target using Marketing Mix $7 P$. This research yield two clusters of students with Dunn Index Value was 1.99. The questionnaire were spreaded to students from the two different clusters dan the results showed that there are three variables of Marketing Mix that potentially increase the market target that is people, product, dan place.
\end{abstract}

Keywords: dunn index, FST UIN Suska, k-means, marketing mix, strategy

\section{PENDAHULUAN (huruf besar, 10pt, tebal)}

Fakultas Sains dan Teknologi UIN Suska Riau (FST UIN Suska) memiliki daya minat yang cukup tinggi dan meningkat setiap tahunnya. Jumlah peminat pada tahun 2014 adalah sebanyak 7334 orang dengan daya tampung 985 orang. Hal ini cukup menggambarkan tingginya minat masyarakat untuk memilih FST UIN Suska. Akan tetapi, secara kualitas 
mahasiswa masih belum mencapai hasil yang diharapkan. Berdasarkan survey awal terhadap dosen di FST UIN Suska, masih terdapat kendala yang cukup besar dalam proses transfer ilmu kepada mahasiswa terutama dalam hal daya tangkap dan pemahaman mahasiswa terhadap materi ajar.

Salah satu faktor yang menyebabkan belum tercapainya kualitas adalah input mahasiswa. Berdasarkan observasi, pada tahun 2015 dan 2016, rata-rata hanya $17,88 \%$ mahasiswa yang berasal dari Pekanbaru (Gambar 1) dimana hanya 35,37\% yang berasal dari sekolah unggulan di Propinsi Riau (Tabel 1). Hal ini menunjukkan bahwa perlu dilakukan strategi promosi yang tepat untuk meningkatkan peluang peningkatan kualitas input sehingga FST UIN Suska tidak hanya unggul secara kuantitas namun juga unggul secara kualitas.

Dalam pencapaian efektifitas promosi PT tersebut, harus ditentukan terlebih dahulu segmen yang tepat untuk mengembangkan sebuah strategi promosi. Hal ini bisa dilakukan melalui segmentasi mahasiswa aktif untuk mengetahui siapa sebenarnya yang menjadi sasaran PT sehingga memudahkan PT dalam melakukan promosi dan sosialisasi dengan tepat. Menurut (Buttle dan Stan 2015), segmentasi pelanggan adalah praktik mempartisi pelanggan menjadi himpunan bagian yang homogen sehingga masing-masing subset dapat ditangani sebagai khalayak pemasaran yang unik. Segmentasi pelanggan biasanya didasarkan pada riset pasar dan demografi (Berry dan Linoff n.d.). Namun menurut (Holmbom dan Eklund 2008) ada dua dasar utama untuk segmentasi, yaitu data demografi (seperti sosial ekonomi dan langkah-langkah gaya hidup) dan langkah-langkah khusus produk (seperti penggunaan produk, sikap pelanggan merek, merek preferensi, manfaat yang dicari dan sensitivitas respons terhadap berbagai kampanye pemasaran). Selanjutnya, apabila segmentasi mahasiswa sudah tergambarkan dengan baik maka dapat dirancang sebuah strategi pemasaran yang tepat sesuai dengan segmentasi yang diperoleh.

Berdasarkan data yang diperoleh dari Pihak akademik Fakultas Sains dan Teknologi pada tahun ajaran 2015/2016 terdapat 1045 mahasiswa baru dengan persentase $16 \%$ berasal dari pekanbaru dan $84 \%$ berasal dari luar pekanbaru. Namun pada tahun ajaran 2016/2017 terjadi peningkatan persentase yang terdiri dari $20 \%$ berasal dari pekanbaru dan $80 \%$ berasal dari luar pekanbaru dengan jumlah mahasiswa baru 686 mahasiswa.

Berbagai metode atau algoritma untuk melakukan segmentasi yang bisa digunakan adalah tools statistik (seperti metode $k$-means clustering dan hierarchical clustering ), data mining (seperti sequence analysis, market basket analysis dan juga neural network), decision tree (misalnya CHAID) dan pendekatan clustering fuzzy (misalnya Fuzzy FCM) (Holmbom dan Eklund 2008). Pada Penelitian ini algoritma yang digunakan adalah algoritma $k$ means untuk melakukan segmentasi calon mahasiswa
FST UIN Suska Riau. Oleh karena K-Means merupakan algoritma yang menentukan jumlah kluster diawal, dan penentuan jumlah kluster pada algoritma K-Means ditentukan sendiri oleh pengguna (Han dan Pei 2012) maka diperlukan algoritma validitas kluster dalam menentukan jumlah kluster yang terbaik. Algoritma validitas yang digunakan dalam penelitian ini adalah Dunn Index (DI). Metode validitas ini berguna untuk melihat jumlah kluster yang terbentuk memiliki nilai kluster yang terbaik. Nilai dunn index terbesarlah yang memiliki nilai kluster yang terbaik (Vendramin dan Hruschka 2009). Dunn Index digunakan karena memiliki nilai validasi terbesar dan baik digunakan pada data numerik dibdaningkan Hubert's statistic, silhoutte coefficient dan Davies Bouldin Index (Retno, 2013). Sedangkan untuk menyusun strategi pemasaran,, peneliti menggunakan metode Marketing Mix yang merupakan salah satu strategi pemasaran yang paling banyak digunakan oleh perusahaan dalam usaha memenangkan pangsa pasar. Strategi ini tidak hanya diaplikasikan pada bisnis produk dan jasa semata, tetapi dapat diterapkan pada promosi perguruan tinggi yang dimasukan ke dalam model bisnis jasa dengan mempertimbangkan aspek 7P yaitu product, price, place, promotion, people, physical evidence, dan process.

\section{METODE PENELITIAN}

Tahapan yang dilalui dalam penelitian ini terdiri dari :

1. Pengumpulan Data

Data yang dikumpulkan pada penelitian ini adalah data mahasiswa semua jurusan yang ada di Fakultas Sains dan Teknologi angkatan 2015, 2016 dan 2017 dengan jumlah 614 data. Berdasarkan data ini akan diperoleh informasi mengenai segmentasi mahasiswa UIN Suska Riau. Sedangkan data untuk untuk merancang strategi pemasaran diperoleh dari data kuesioner.

2. Pengolahan data dengan algoritma K-Means dan metode Dunn Index

Setelah data yang diperlukan terkumpul, maka dilakukan pengolahan data dengan algoritma KMeans dan divalidity dengan menggunakan metode Dunn Index.

3. Rancangan Strategi Pemasaran

Setelah mengetahui segmentasi mahasiswa FST UIN Suska Riau, selanjutnya dirancang strategi apa yang tepat unruk memasarkan brdan FST UIN Suska Riau dengan metode Marketing Mix Strategy, adapun tahapan pengolahan datanya sebagai berikut:

a. Menentukan populasi dan sampel dan menyusun kuesioner menggunakan 7 variabel marketing mix.

7 Variabel marketing mix (7P) yang digunakan dalam penelitian ini adalah : Product, Price, Promotion, Place, People, Process, Physical Evidence. 
b. Penyebaran kuesioner

Kuesioner disebarkan kepada sampel data yang telah diolah.

c. Uji validity dan reliabilitas hasil kuesioner dengan menggunakna software SPPS windows 21

d. Merancang strategi pemasaran dengan marketing mix strategy

Setelah diketahui indikator-indikator apa saja yang menjadi daya tarik FST UIN Suska Riau, dibuatlah strategi untuk memasarkan brdan FST UIN Suska Riau.

\section{TINJAUAN PUSTAKA}

\subsection{Segmentasi dan Target Pasar (Mahasiswa)}

Menurut (Buttle 2008), segmentasi pelanggan adalah praktik mempartisi pelanggan menjadi himpunan bagian yang homogen sehingga masingmasing subset dapat ditangani sebagai khalayak pemasaran yang unik. Segmentasi dilakukan dengan maksud untuk memudahkan perusahaan dalam melakukan pemasaran dalam hal ini yaitu Perguruan Tinggi. Dengan melakukan segmentasi tersebut PT mengetahui kebutuhan dan keinganan tiap kelompok yang spesifik sehingga perusahaan mudah memasarkan produk dan jasa sesuai dengan kebutuhan tiap-tiap segmen dalam hal ini yaitu seperti fasilitas, sarana dan prasarana dan sebagainya.

\subsection{Algoritma K-Means}

K-Means merupakan algoritma yang termasuk pada kategori metode klustering partisi (Kdaneil, Saad, dan Youssef 2014) yang umum digunakan oleh beberapa peneliti dan penggunaannya pun sederhana (Berry dan Linoff n.d.). Meskipun algoritma ini telah banyak digunakan dalam berbagai bidang (Sitanggang dan Baehaki 2015) namun algoritma ini memiliki kelemahan yaitu sangat sensitif terhadap pilihan starting point (Hosseini, Maleki, dan Gholamian 2010) dan juga sensitif terhadap outlier dikerenakan objek-objek tersebut mendistorsi nilai rata-rata kluster (Han, Kamber, dan Pei 2012).

Tahapan dalam metode K-means adalah sebagai berikut :

[1] Tentukan jumlah kluster

[2] Pilih centroid awal secara acak sesuai jumlah kluster yang telah ditentukan

[3] Hitung jarak data ke centroid dengan rumus euclidean distance pada persamaan 1 .

$\mathrm{d}_{\mathrm{xy}}=\sqrt{\sum_{i=1}^{n}\left(x_{i}-y_{i}\right)^{2}}$

[4] Perbaharui centroid dengan menghitung nilai ratarata nilai pada masing-masing kluster

[5] Kembali ke tahapan ke 3 jika masih terdapat data yang berpindah kluster atau perubahan nilai centroid
Algoritma K-Means pada penelitian ini digunakan untuk melakukan segmentasi mahasiswa sehingga dihasilkan beberapa kluster yang sesuai dengan segmen masing-masing.

\subsection{Metode Dunn Index}

Dunn Index adalah metode validity kluster yang didasarkan pada perhitungan geometri dari kekompakan masing-masing kluster dan pemisahan antar kluster (Retno 2013) dengan nilai Dunn Index (DI) terbesar yang memiliki kluster terbaik (Vendramin dan Hruschka 2009). Kluster terbaik dilihat dengan nilai DI yang terbesar (Vendramin dan Hruschka 2009). Dunn index di hitung berdasarkan persamaan berikut :

$D_{n c}=\min _{i=1, \ldots, n c}\left\{\min _{j=i+1, \ldots, n c}\left(\frac{d\left(c_{i}, c_{j}\right)}{\max _{k=1 . \ldots, n c} \operatorname{diam}\left(c_{k}\right)}\right)\right\}$

Dimana $d(c i, c j)$ adalah fungsi yang tidak sama antara kluster $c i$ dan $c j$ yang didefinisikan sebagai :

$$
d(c i, c j)=\min _{x \in c_{i}, y \in c_{j}} d(\mathbf{x}, \mathbf{y})
$$

dan $\operatorname{diam}(C)$ adalah diameter kluster yang mungkin dpertimbangkan sebagai ukuran dispersion kluster. Diameter kluster $\mathrm{C}$ bisa dedefinisikan sebagai :

$$
\operatorname{diam}(C)=\max _{x, y \in C} d(\mathbf{x , y})
$$

\subsection{Marketing Mix}

Pemasaran tradisional dikenal dengan $4 \mathrm{P}$ yaitu product, price, place dan promotion. Namun dengan perkembangan zaman saat ini maka pelanggan menjadi lebih canggih maka ditambahkan 3P terutama untuk layanan industri (Hashim dan Hamzah 2014). Penambahan variabel tersebut adalah people, process dan physical environment (Hashim dan Hamzah 2014). Dengan penambahan 3 variabel tersebut dikenal dengan $7 \mathrm{P}$ yang disebut dengan marketing mix. Menurut (Kotler dan Keller 2008) 7P didefinisikan sebagai berikut:

a. Product (Produk)

Produk adalah segala sesuatu yang dapat ditawarkan kepada pasar untuk memuaskan suatu keinginan atau kebutuhan konsumen. Produk dapat berupa sub kategori yang menjelaskan dua jenis seperti barang dan jasa yang ditujukan kepada target pasar.Dalam Perguruan Tinggi produk disini bisa dianggap jurusan.

b. Price (Harga)

Harga adalah sejumlah uang yang mempunyai nilai tukar untuk memperoleh keuntungan dari memiliki atau menggunakan suatu produk atau jasa. Harga merupakan bauran pemasaran yang bersifat fleksibel dimana suatu harga akan stabil dalam jangka waktu tertentu tetapi dalam seketika harga dapat meningkat atau menurun yang terdapat pada pendapatan dari hasil 
penjualan. Pada Perguruan Tinggi harga yakni biaya masuk dan biaya semester yang dikeluarkan mahasiswa pada PT.

c. Promotions (Promosi)

Promosi adalah kegiatan mengkomunikasikan informasi dari penjual kepada konsumen atau pihak lain dalam saluran penjualan untuk mempengaruhi sikap dan perilaku. Media promosi yang dapat digunakan pada bisnis ini antara lain (1) Periklanan, (2) Promosi penjualan, (3) Publisitas dan hubungan masyarakat, dan (4) Pemasaran langsung. Penentuan media promosi yang akan digunakan didasarkan pada jenis dan bentuk produk itu sendiri.

d. Place (Tempat)

Place merupakan distribusi layanan melalui fisik dan non fisik. Distribusi berkaitan dengan kemudahan memperoleh produk di pasar dan tersedia saat konsumen mencarinya. Distribusi memperlihatkan berbagai kegiatan yang dilakukan perusahaan untuk menjadikan produk atau jasa dipe roleh dan tersedia bagi konsumen sasaran.

e. People (Orang)

People yaitu proses seleksi, pelatihan, dan pemotivasian karyawan yang nantinya dapat digunakansebagai pembedaan perusahaan dalam memenuhi kepuasan pelanggan.

f. Process (Proses)

Proses merupakan bentuk kegiatan yang dilakukan untuk memasarkan produk barang atau jasa kepada calon pelanggan.

g. Physical Evidence (Lingkungan Fisik)

Bukti fisik yaitu bukti yang dimiliki oleh penyedia jasa yang ditujukan kepada konsumen sebagai usulan nilai tambah konsumen. Bukti fisik merupakan wujud nyata yang ditawarkan kepada pelanggan ataupun calon pelanggan.

\section{HASIL DAN PEMBAHASAN}

\subsection{Validity Data}

Data yang digunakan pada penelitian ini berasal dari mahasiswa Fakultas Sain dan Teknologi angkatan 2017/2018 dan 2018/2019. Data yang telah dikumpulkan akan divalidity berdasarkan Nama dan NIM mahasiswa. Validity dilakukan karena terdapatnya data mahasiswa gdana, kosong atau kurang jelas serta pemilihan atribut yang digunakan pada penelitian ini. Validity dilakukan dengan tujuan membersihkan data (cleaning). Jumlah data awal yang belum divalidity dan dicleaning berjumlah 778 dan yang telah melalui tahapan validity dan cleaning data berjumlah 614 .

\subsection{Pengolahan Data}

Setelah melakukan validity dan pembersihan data, selanjutnya data tersebut dikelompokkan berdasarkan jalur Masuk. Jumlah data per jalur masuk dapat dilihat pada Tabel 1. Selanjutnya data per jalur masuk akan di nominalkan agar bisa dilakukan klustering data. Data nominal berdasarkan atribut dapat dilihat pada Tabel 2. Setelah atribut tersebut dinominalkan maka data mahasiswa yang telah didapat akan di inputkan berdasarkan atribut yang dapat dilihat pada Tabel 3 yang merupakan data mentah yang telah dinominalkan.

\begin{tabular}{|c|c|c|c|}
\hline & \multicolumn{2}{|c|}{ Nama Jalur Masuk } & Jumlah Mahasiswa \\
\hline & \multicolumn{2}{|l|}{ PBUD } & 17 \\
\hline & \multicolumn{2}{|c|}{ PMB Tulis 1} & 152 \\
\hline & \multicolumn{2}{|c|}{ SBMPTN } & 245 \\
\hline & \multirow{2}{*}{\multicolumn{2}{|c|}{$\begin{array}{l}\text { SNMPTN } \\
\text { SNPTKIN }\end{array}$}} & 157 \\
\hline & & $\begin{array}{l}\text { UMPTKIN } \\
\text { UN Mdaniri }\end{array}$ & 2 \\
\hline & UN Mdan & & 41 \\
\hline \multicolumn{4}{|c|}{ Tabel 2. Data Nominal Berdasarkan Atribut } \\
\hline \multirow{3}{*}{$\begin{array}{ll}\text { No. } \\
1\end{array}$} & Atribut & & Data Nominal \\
\hline & Jenis Kelamin & 1. & Laki \\
\hline & $(\mathrm{JK})$ & 2. & Perempuan \\
\hline \multirow[t]{7}{*}{2} & Asal Sekolah & 1. & Riau \\
\hline & (AS) & 2. & Kepulauan Riau \\
\hline & & 3. & Jawa \\
\hline & & 4. & Sumatera Barat \\
\hline & & 5. & Sumetara Utara \\
\hline & & 6. & Jambi \\
\hline & & 7. & Bengkulu \\
\hline \multirow[t]{5}{*}{3} & Jurusan Saat ini & 1. & Teknik Informatika \\
\hline & (Jur) & 2. & Teknik Industri \\
\hline & & 3. & Sistem Informasi \\
\hline & & 4. & Matematika Terapan \\
\hline & & 5. & Teknik Elektro \\
\hline \multirow[t]{3}{*}{4} & Pilihan Lulus & 1. & Pilihan 1 \\
\hline & (PL) & & Pilihan 2 \\
\hline & & 3. & Pilihan 3 \\
\hline \multirow[t]{4}{*}{5} & Pendapatan & 1. & Rp. $1.000 .000-2.000 .000$ \\
\hline & Orangtua (PO) & 2. & Rp. $2.000 .000-4.000 .000$ \\
\hline & & 3. & Rp. $4.000 .000-6.000 .000$ \\
\hline & & 4. & Rp. $>6.000 .00$ \\
\hline \multirow[t]{7}{*}{6} & Besaran UKT & 1. & UKT 1 \\
\hline & (BU) & 2. & UKT 2 \\
\hline & & 3. & UKT 3 \\
\hline & & & UKT 4 \\
\hline & & 5. & UKT 5 \\
\hline & & 6. & UKT 6 \\
\hline & & 7. & UKT 7 \\
\hline \multirow[t]{6}{*}{7} & Jalur Masuk(JM) & 1. & PBUD \\
\hline & & & PMB Tulis 1 \\
\hline & & & SBMPTN \\
\hline & & & SNMPTN \\
\hline & & 5. & UMPTKIN \\
\hline & & 6. & UN Mdaniri \\
\hline
\end{tabular}

Data yang telah dinominalkan akan dikluster dengan algoritma K-Means. Namun, algoritma ini memiliki kelemahan yaitu penentuan jumlah kluster ditentukan oleh pengguna. Oleh karena itu, dibutuhkan metode validity kluster. Salah satu metode validity kluster adalah Dunn Index. Dunn Index (DI) adalah metode validity kluster yang didasarkan pada perhitungan geometri dari kekompakan masing-masing kluster dan pemisahan antar kluster (Retno 2013) dengan nilai dunn index terbesar yang memiliki kluster terbaik (Vendramin dan Hruschka 2009). Perhitungan Dunn Index 
menggunakan persamaan 2. Hasil Jumlah Kluster berdasarkan nilai DI dapat dilihat pada Tabel 4.

Tabel 3 Data mentah yang telah dinominalkan

\begin{tabular}{llllllll}
\hline No. & JK & AS & Jur & PL & PO & BU & JM \\
\hline 1 & 1 & 1 & 1 & 1 & 4 & 4 & 2 \\
2 & 1 & 1 & 5 & 1 & 1 & 2 & 1 \\
3 & 1 & 1 & 1 & 1 & 1 & 3 & 3 \\
4 & 1 & 1 & 2 & 1 & 2 & 3 & 1 \\
5 & 1 & 1 & 5 & 2 & 1 & 3 & 3 \\
6 & 1 & 1 & 1 & 2 & 2 & 3 & 3 \\
7 & 1 & 1 & 5 & 3 & 1 & 1 & 3 \\
8 & 1 & 1 & 2 & 1 & 2 & 3 & 6 \\
9 & 2 & 5 & 1 & 1 & 2 & 3 & 2 \\
10 & 1 & 1 & 1 & 1 & 4 & 4 & 2 \\
$\ldots$ & & & & & & & \\
614 & 1 & 1 & 2 & 1 & 1 & 2 & 2 \\
\hline
\end{tabular}

Berdasarkan Tabel 4, nilai Dunn Index tertinggi adalah 1.99 dengan jumlah kluster adalah 2. Oleh karena itu, data 614 tersebut dikluster menjadi dua kluster dengan menggunakan algoritma K-means dengan jumlah masing-masing kluster dapat dilihat Tabel 5. Pada Tabel 5 terdapat jumlah data mahasiswa yang sama yaitu pada kluster 1 menghasilkan jumlah data 307 dan kluster 2 berjumlah 307 juga. Hasil 307 tersebut merupakan nilai kebetulan sama bukan hasil pembagian dua dari 614. Hasil data yang telah dikluster terdapat pada Tabel 6 dan Tabel 7.

Berdasarkan Tabel 6 diatas, maka dapat dianalisis bahwa jenis kelamin yang paling banyak adalah laki-laki dengan asal sekolah terbanyak berasal dari Riau, jurusan terbanyak yaitu teknik Informatika, pilihan lulus 1, pendapatan Orang tua berada di antara 1-2 juta per bulan sehingga UKT terbanyak berada pada UKT 3 dan jalur lulus terbanyak adalah SBMPTN. Begitu juga pada kluster 2 pada Tabel 8 yaitu laki-laki dengan asal sekolah terbanyak berasal dari Riau, jurusan terbanyak Ssitem Informasi, pilihan lulus 1 dengan pendapatan Orang tua berada di antara 1-2 juta per bulan sehingga UKT terbanyak yaitu UKT 3 dan jalur lulus terbanyak adalah SBMPTN.

\begin{tabular}{|c|c|c|}
\hline No. & Jumlah kluster & Nilai Dunn Index \\
\hline 1 & 2 & 1.99 \\
\hline 2 & 3 & 1.98 \\
\hline 3 & 4 & 1.97 \\
\hline 4 & 5 & 1.94 \\
\hline 5 & 6 & 1.96 \\
\hline 6 & 7 & 1.94 \\
\hline 7 & 8 & 1.87 \\
\hline 8 & 9 & 1.89 \\
\hline 9 & 10 & 1.82 \\
\hline \multicolumn{3}{|c|}{ Tabel 5. Jumlah data pada setiap kluster } \\
\hline No. & Nama Kluster & Jumlah Data \\
\hline 1 & 1 & 307 \\
\hline 2 & 2 & 307 \\
\hline
\end{tabular}

Berdasarkan segmentasi mahasiswa pada kluster 1 dan kluster 2 didapatlah hasil bahwa target mahasiswa pada penelitian ini adalah Mahasiswa yang berasal dari Riau dengan Jurusan terbanyak TIF, TI dan SI dengan jalur lulus masuk yaitu SBMPTN. Berdasarkan hasil tersebut maka langkah penelitian selanjutnya adalah menyebarkan kuesioner kepada mahasiswa dengan ciri-ciri pada Tabel 8 untuk mengetahui strategi yang akan di rancang pada penelitian ini.

Tabel 6. Hasil Data Kluster 1

\begin{tabular}{|c|c|c|c|c|c|c|c|c|c|c|c|c|c|}
\hline \multicolumn{2}{|c|}{ JK } & \multicolumn{2}{|l|}{ AS } & \multicolumn{2}{|c|}{ Jur } & \multicolumn{2}{|c|}{ PL } & \multicolumn{2}{|c|}{ PO } & \multicolumn{2}{|c|}{ BU } & \multicolumn{2}{|l|}{ JM } \\
\hline $\mathrm{L}$ & 188 & Riau & 229 & TIF & 77 & Pil 1 & 194 & $1 \mathrm{jt}-2 \mathrm{jt}$ & 137 & 1 & 9 & PBUD & 9 \\
\hline \multirow[t]{6}{*}{$P$} & 119 & Kepri & 12 & TI & 76 & Pil 2 & 55 & $2 \mathrm{jt}-4 \mathrm{jt}$ & 122 & 2 & 63 & PMB Tulis 1 & 72 \\
\hline & & Jawa & 5 & SI & 65 & Pil 3 & 58 & $4 \mathrm{jt}-6 \mathrm{jt}$ & 36 & 3 & 129 & SBMPTN & 124 \\
\hline & & Sumbar & 54 & MT & 39 & & & $>6 \mathrm{jt}$ & 12 & 4 & 69 & SNMPTN & 78 \\
\hline & & Sumut & 7 & $\mathrm{TE}$ & 50 & & & & & 5 & 31 & UMPTKIN & 0 \\
\hline & & Jambi & & & & & & & & 6 & 3 & UN Mdaniri & 24 \\
\hline & & Bengku & & & & & & & & 7 & 3 & & \\
\hline & 07 & 307 & & & & & & & & & & 307 & \\
\hline
\end{tabular}

Tabel 7. Hasil Data Kluster 2

\begin{tabular}{|c|c|c|c|c|c|c|c|c|c|c|c|c|c|}
\hline JK & & AS & & Jur & & PL & & PO & & $\mathbf{B U}$ & & $\mathbf{J M}$ & \\
\hline $\mathrm{L}$ & 158 & Riau & 245 & TIF & 70 & Pil 1 & 198 & $1 \mathrm{jt}-2 \mathrm{jt}$ & 135 & 1 & 13 & PBUD & 8 \\
\hline \multirow[t]{6}{*}{$\mathrm{P}$} & 149 & Kepri & 12 & TI & 59 & Pil 2 & 44 & $2 \mathrm{jt}-4 \mathrm{jt}$ & 119 & 2 & 53 & PMB Tulis 1 & 80 \\
\hline & & Jawa & 3 & SI & 94 & Pil 3 & 65 & $4 \mathrm{jt}-6 \mathrm{jt}$ & 41 & 3 & 118 & SBMPTN & 121 \\
\hline & & Sumbar & 36 & MT & 46 & & & $>6 \mathrm{jt}$ & 12 & 4 & 83 & SNMPTN & 79 \\
\hline & & Sumut & 7 & $\mathrm{TE}$ & 38 & & & & & 5 & 37 & UMPTKIN & 2 \\
\hline & & Jambi & 3 & & & & & & & 6 & 2 & UN Mdaniri & 17 \\
\hline & & Bengk & 1 & & & & & & & 7 & 1 & & \\
\hline 307 & & 307 & & 307 & & 307 & & 307 & & 307 & & 307 & \\
\hline
\end{tabular}

Berdasarkan Tabel 8 maka di dapatlah 474 mahasiswa yang berasal dari 3 jurusan yang memliki jumlah mahasiswa terbanyak pada Fakultas Sains dan Teknologi. Jumlah 474 mahasiswa tersebut akan dilakukan pemilihan data mahasiswa yang berasal dari sekolah di Riau untuk merancang strategi pemasaran. 


\begin{tabular}{|c|c|c|c|}
\hline Asal Sekolah & $\begin{array}{c}\text { Total } \\
\text { Semua } \\
\text { Jurusan }\end{array}$ & Jurusan & Jumlah \\
\hline Riau & 474 & $\begin{array}{l}\text { TIF } \\
\text { TI } \\
\text { SI }\end{array}$ & $\begin{array}{l}42 \\
31 \\
46\end{array}$ \\
\hline
\end{tabular}

\subsection{Rancangan Strategi Pemasaran}

Setelah mengetahui segmentasi mahasiswa UIN Suska Riau, selanjutnya dirancang strategi apa yang tepat untuk memasarkan brand UIN Suska Riau dengan metode Marketing Mix Strategy.

a. Menentukan populasi dan sampel

Berdasarkan hasil cluster dengan menggunakan algoritma K-Means, didapatkan 474 jumlah populasi. Dari 474 populasi diambil sampel yang berasal dari 3 program studi yaitu prodi TIF, TI dan SI yang berjumlah 119 responden yang berasal dari Riau. Jurusan ini diambil karena tiga jurusan ini adalah jurusan yang memiliki populasi mahasiswa yang berasal dari Riau terbanyak.

b. Uji validity dan reliabilitas hasil kuesioner dengan menggunakna software SPPS windows 21.

Penyebaran kuisioner awal untuk Uji validity dan reliabilitas disebarkan kepada 30 responden. Hasil dari uji validity dan reliabilitas disajikan pada Tabel 9 dan Tabel 10. Pernyataan kuesioner dapat dilihat pada Tabel 11.

\begin{tabular}{clll}
\multicolumn{4}{c}{ Tabel 9. Hasil Uji Validity } \\
\hline Case & Kriteria & $\mathbf{N}$ & $\mathbf{\%}$ \\
\hline case & Valid & 30 & 100,0 \\
& Excluded & 0 & 0 \\
& Total & 30 & 100.0 \\
\hline \multicolumn{4}{c}{ Tabel 10. Hasil Uji Reliability } \\
\hline $\begin{array}{c}\text { Cronbach's } \\
\text { Alpha }\end{array}$ & $\begin{array}{c}\text { Cronbach's Alpha } \\
\text { Based on }\end{array}$ & N of \\
\multicolumn{4}{c}{ Items } \\
\hline, 852 & \multicolumn{2}{c}{ Stdanardized Items } \\
\hline \multicolumn{3}{c}{, 854} & 25 \\
\hline
\end{tabular}

Tabel 11. Pernyataan Kuesioner

\begin{tabular}{|c|c|c|}
\hline No & Variabel & Pernyataan \\
\hline 1 & Product & Mutu pendidikan/Akademik baik \\
\hline 2 & & Prospek mendapatkan pekerjaan/karir dengan cepat \\
\hline 3 & & Terdapat pilihan konsentrasi (fakultas dan jurusan) bervariasi \\
\hline 4 & & Terdapat mata kuliah tentang basic keislaman \\
\hline 5 & Price & Biaya pendidikan (SPP, biaya pembangunan, biaya laboratorium) terjangkau \\
\hline 6 & & Adanya pemberian beasiswa \\
\hline 7 & & Sistem pembayaran yang fleksibel (terdapat syarat cicilan pembayaran) \\
\hline 8 & Promotion & Kemudahan akses menuju kampus dapat dicapai dengan alat transportasi umum \\
\hline 9 & & Kedekatan lokasi kampus dengan fasilitas umum \\
\hline 10 & & Tersedianya situs/web kampus \\
\hline 11 & Place & Promosi (iklan, surat kabar, tv, radio dan brosur) berkontribusi dalam pemilihan universitas \\
\hline 12 & & Kegiatan kehumasan (mengadakan event dan undangan kunjungan) berkontribusi dalam pemilihan universitas \\
\hline 13 & & Adanya interaksi langsung dengan calon mahasiswa dan masyarakat \\
\hline 14 & People & Dosen yang berkualitas \\
\hline 15 & & Memiliki guru besar/professor dan dosen dengan gelar akademis lainnya \\
\hline 16 & & Administrator /pemimpin yang berkompeten \\
\hline 17 & & Tenaga kependidikan (administrasi dan staf) yang professional \\
\hline 18 & Process & Perkuliahan (proses pembelajaran) yang baik \\
\hline 19 & & Pelayanan jasa administrasi yang akurat, responsive, peduli terhadap kebutuhan mahasiswa \\
\hline 20 & Physical-Evidence & Desain/gaya gedung dan ruang kelas memadukan antara estetika dan fungsional \\
\hline 21 & & Fasilitas sarana dan prasarana penunjang lengkap dan memadai (lab, perpustakaan, saana ibadah, lahan parkir) \\
\hline 22 & & Penggunaan teknologi pada bangunan dan sarana prasarana \\
\hline 23 & & Tersedia asrama/pondok (Ma'had) \\
\hline 24 & & Reputasi institusi baik ( status, rangking, dan pencapaian/prestasi universitas) \\
\hline 25 & & Kredibilitas (tingkat kepercayaan public) tinggi \\
\hline
\end{tabular}

c. Penyebaran kuisioner kepada responden penelitian.

Kuisioner disebarkan kepada 119 responden, 3 responden tidak mengisi, jadi jumlah kuisiner yang kembali sebanyak 116 keuisioner. Dari hasil rekapitulasi kuisioner dilakukan pengolahan untuk melihat variabel apa saja yang sangat berpengaruh untuk melakukan pemasaran. Hal ini bisa dilihat dari nilai rating score yang terdapat pada Tabel 12. Hasil dari perhitungan rating skor marketing mix ada 3 variabel yang sangat berpengaruh dalam pemilihan universitas yaitu people, product dan Place.

\begin{tabular}{ll}
\multicolumn{2}{c}{ Tabel 12. Rating Score } \\
\hline Variabel & Rating score \\
\hline People & 380 \\
Product & 374.3 \\
Place & 373.7 \\
Physical evidence & 368.8 \\
Process & 365.5 \\
Promotion & 350.7 \\
Price & 331.7 \\
\hline
\end{tabular}

d. Merancang strategi pemasaran dengan marketing mix strategy

Perancangan strategi dilakukan dengan metode brain storming yang menghadirkan beberapa pakar dibidang marketing. Pakar yang dilibatkan dalam perancangan startegi ini adalah bagian humas UIN Suska Riau dan Dosen bidang marketing mix di UIN 
Suska Riau. Berdasarkan hasil penelitian dan diskusi dengan pakar, dapat dirancang strategi pemasaran Fakultas Sains dan Teknologi UIN Suska Riau, yaitu:

1) Berdasarkan variabel People, langkah yang bisa dilakukan adalah:

a. Mendokumentasikan hasil penelitian dosen terutama penelitian yang mengintegrasikan dengan keislaman, dalam bentuk multi media dan menyebarluaskannya baik secara langsung maupun melalui web dan media social lainnya.

b. Dengan strategi ini bisa menonjolkan prestasi dosen dalam bidang penelitian dan menggambarkan penerapan keilmuan yang nantinya akan di dapatkan mahasiswa ketika berada di bangku kuliah.

c. Pada saat melakukan sosialisasi baik secara langsung maupun melalui web dan media sosial lainnya, juga menginformasikan tentang jabatan fungsional dosen dan latar belakang pendidikan dosen. Selain itu juga menginformasikan tentang latar belakang pendidikan pegawai dan staf di FST UIN Suska Riau.

d. Mendokumentasikan hasil pengabdian yang dilakukan oleh dosen dalam bentuk multi media dan menyebarluaskannya baik secara langsung maupun melalui web dan media sosial lainnya. Hal ini dilakukan untuk memperlihatkan peran dosen secara langsung dalam kegiatan kemasyarakatan terkait dengan penerapan ilmu dan integrasi keislaman di program studi FST UIN Suska Riau.

2) Berdasarkan variabel Product, langkah yang bisa dilakukan adalah:

a) Pengenalan produk diutamakan pada sosialisasi kurikulum berbasis keislaman sebagai ciri khas dari UIN Suska Riau.

b) Menonjolkan mutu pendidikan di FST UIN Suska Riau seperti: pencapaian kesuksesan alumni di dunia kerja dan wirausaha, kurikulum yang sesuai dengan kebutuhan dunia kerja, prestasi yang telah dicapai mahasiswa dibidang akademis dan non akademis.

c) Menunjukkan hasil tracer study yang memperlihatkan bahwa lama waktu menunggu alumni untuk bekerja tidak terlalu lama.

d) Menginformasikan bahwa fakultas sains dan teknologi menawarkan beberapa pilihan program studi serta kelebihan dari masingmasing program studi.

3) Berdasarkan variabel Place, langkah yang bisa dilakukan adalah menginformasikan lokasi kampus yang mudah diakses dan didukung dengan pertumbuhan fasilitas umum disekitar kampus (transportasi, rumah kos, swalayan, rumah makan, percetakan, asrama kampus dll).
Menginformasikan alamat web FST UIN Suska riau, sehingga lebih mudah dalam mengakses semua aktifitas kampus.

\section{KESIMPULAN DAN SARAN}

Segmentasi mahasiswa terdiri dari dua kluster dengan jumlah masing - masing data pada kluster yaitu 307. Masing-masing kluster memiliki target mahasiswa. Target mahasiswa untuk calon mahasiswa FST UIN Suska berasal dari asal sekolah dari RIAU pada jurusan Teknik Informatika dan Sistem Informasi pada jalur masuk SBMPTN. Berdasarkan hasil segmentasi tersebut maka strategi yang bisa dirancang adalah menonjolkan prestasi dosen, pebanyak melakukan pengabdian ke masyarakat, kurikulum diperkuat dengan basic keislaman, menonjolkan mutu pendidikan dengan pencapaian alumni, perbanyak fasilitas akses ke lokasi kampus, serta website kampus yang mudah diakses dan terupdate.

\section{UCAPAN TERIMA KASIH}

Terimakasih kepada Pihak akademik dan Mahasiswa UIN Suska khususnya FST angkatan 2017/2018 dan 2018/2019 dan LPPM UIN Suska atas dukungan yang telah diberikan dalam menyelesaikan penelitian ini.

\section{DAFTAR PUSTAKA}

BERRY, MICHAEL J A, DAN GORDON S LINOFF. 2012. Data Mining Techniques for Merketing, Sales dan Customer Relationship Management. Second edi. Wiley

BUTTLE, FRANCIS. 2008. Elsevier ButterworthHeinemann Customer Relation Management,Concept dan Technologies, Second Edition.

BUTTLE, FRANCIS, DAN MAKLAN STAN. 2015. Customer Relationship Management. Third edit. Butterworth-Heinemann.

HAN, JIAWEI, MICHELINE KAMBER, DAN JIAN PEI. 2012. San Francisco, CA, itd: Morgan Kaufmann Data Mining: Concepts dan Techniques.

HASHIM, NURHAZIRAH, DAN MUHAMMAD ISKDANAR HAMZAH. 2014. "7P' S : A Literature Review of Islamic Marketing dan Contemporary Marketing Mix." Procedia Social dan Behavioral Sciences 130: 155-59.

HOLMBOM, ANNIKA H, DAN TOMAS EKLUND. 2008. "Customer Portfolio Analysis Using the SOM.” (2007): 412-22.

HOSSEINI, SEYED MOHAMMAD SEYED, ANAHITA MALEKI, DAN MOHAMMAD REZA GHOLAMIAN. 2010. "Cluster Analysis Using Data Mining Approach to Develop CRM Methodology to Assess the Customer Loyalty." Expert Systems with Applications 37(7): 525964. 
68 Jurnal Teknologi Informasi dan Ilmu Komputer (JTIIK), Vol. 8, No. 1, Februari 2021, hlm. 61-68

KDANEIL, DALIA ABDELRAZEK, AMANI ANWAR SAAD, DAN SHERIN MOUSTAFA YOUSSEF. 2014. "A Two-Phase Clustering Analysis for B2B Customer Segmentation." Proceedings - 2014 International Conference on Intelligent Networking dan Collaborative Systems, IEEE INCoS 2014: 221-28.

KOTLER, PHILIP, DAN KEVIN LANE KELLER. 2008. "Manajemen Pemasaran Penerbit Jakarta : Erlangga."

RETNO, DEWANTI. 2013. "Perbdaningan Metode Cluster Validity Pada." Skripsi Fakultas Matematika Dan Ilmu Pengetahuan Alam, Institut Pertanian Bogor.

SITANGGANG, IMAS SUKAESIH, DAN DHIYA AULIA MUHAMAD BAEHAKI. 2015. "Global dan Collective Outliers Detection on Hotspot Data as Forest Fires Indicator in Riau Province, Indonesia." ICSDM 2015 Proceedings 2015 2nd IEEE International Conference on Spatial Data Mining dan Geographical Knowledge Services: 66-70.

VENDRAMIN, LUCAS, DAN EDUARDO R HRUSCHKA. 2009. "On the Comparison of Relative Clustering Validity Criteria *." : 733744. 